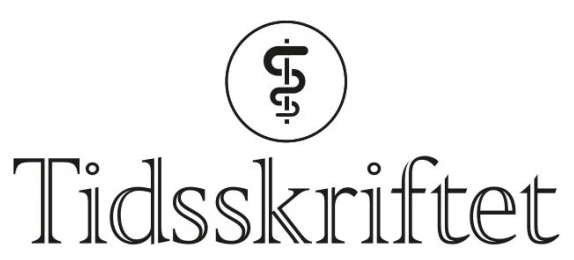

DEN NORSKE LEGEFORENING

\title{
Nei, livserfaring gjør deg ikke til en bedre lege
}

KOMMENTAR

\section{ELLEN MARIE SAETHRE-MCGUIRK}

ellen.m.sathre-mcguirk@nord.no

Ellen Marie Sæthre-McGuirk er professor.

Forfatteren har ikke oppgitt noen interessekonflikter.

Nylig stilte Kaveh Rashidi spørsmålet «Gjør livserfaring oss til bedre leger?»(1). Han utdypet at brukt på riktig måte kan livserfaringer være en ressurs i profesjonsutøvelsen. Som pårørende er jeg langt på vei enig. Jeg foreslår likevel som motsvar: Nei, livserfaring gjør deg ikke til en bedre lege.

Misforstå meg rett. Utdanning og kompetanse kommer først, men om jeg kan velge, velger jeg en lege som er eldre enn meg selv. En som har opplevd sorg og kommet seg igjennom prøvelser. En med egne laster. En som har hatt små barn. Og gamle foreldre.

Ikke fordi jeg vet at slike livserfaringer gjør en til en bedre lege, men fordi jeg har erfart at mangelen på det gjør en til en mer umoden lege. Som student pugger du teori, innhenter praksiserfaring og lærer å identifisere relevante objektive parametere for å kunne generere en diagnose. Men, det å kunne se pasienten i lys av diagnosen og hvordan diagnosen vil påvirke pasienten som menneske krever bred innsikt og erfaring med et livsløp av sosiale samspill og forskjellige skjebner.

En moden lege kan også se at pårørende er en viktig del av pasientens liv og at de spiller de inn på pasientens subjektive situasjons- og helseforståelse. Jeg er enig med Rashidi i at en moden lege som selv har erfart kreft i familien skjønner kreftens ringvirkninger. Den har kjent på hvordan kreften tar hold i pasienten samtidig som den også tar hold i de pårørende som individer og som familie. Kanskje gir dette en mer nyansert forståelse av pasientens helsetilstand. Som lege til en av de pårørende er du kanskje mer oppmerksom på hvordan kreften tærer på dem også. Kanskje.

Og kanskje ikke. Det er ikke livserfaring eller den personlige erfaringen med noe som pasienten eller de pårørende gjennomgår som gjør en til en bedre lege. Ikke hver eneste LIS eller konstituert overlege må ha først ha hatt kreft eller vært kreftpårørende for å kunne bli overlege eller en bedre onkolog.

Det er nemlig forskjell på en moden og en bedre lege. 
Den modne profesjonskunnskapen må videreutvikles med refleksjon. Å reflektere over prosessene du har vært en del av er å kritisk ta for deg hvordan du som lege utøvde ditt legearbeid i møtene du har hatt med pasienter og pårørende. Over tid vil denne refleksjonsøvelsen gi grunnlag for en nyansert taus kunnskap; en praktisk kunnskap. Med denne kan du kontinuerlig systematisere ny og gammel menneskeinnsikt og erfaring, utvikle ny kunnskap om hvordan du påvirkes av dine egne sosiale strukturer og relasjoner og hvordan du bevisst og ubevisst påvirker både pasienten og de pårørende med hvert ord og på hvert møte. Hvor en moden lege har lært mye om andre mennesker, vil jeg påstå at en bedre lege har også lært mye om seg selv i møte med andre mennesker.

Det bør være mer fokus på legens praktiske kunnskap og innsikt i det som skjer mellom legen og pasienten/pårørende; det rommet i tid og sted som er utover de objektive parameterne, subjektive vurderingene og faglige beslutningene. Så nei, livserfaring gjør deg ikke til en bedre lege. Men kanskje vil mer refleksjon gjøre det.

\section{LITTERATUR}

1. Rashidi K. Gjør livserfaring oss til bedre leger? Tidsskr Nor Legeforen 2020; 140. doi: 10.4045/tidsskr.20.0503. [CrossRef]

Publisert: 28. september 2020. Tidsskr Nor Legeforen. DOI: 10.4045/tidsskr.20.0706

(C) Tidsskrift for Den norske legeforening 2023. Lastet ned fra tidsskriftet.no 26. april 2023. 